\title{
Above-ground carbon stock at Kamojang Regions, West Java, Indonesia
}

\author{
DWIKI DANANG KUNCORO ${ }^{1, \bullet}$, TEGUH HUSODO ${ }^{1}$, JOKO KUSMORO ${ }^{1}$, RANDI HENDRAWAN ${ }^{1}$, \\ SUROSO $^{1}$, FEMI AFRIYANTI ${ }^{2, \vee v}$, ERRI NOVIAR MEGANTARA ${ }^{\mathbf{1}}$ \\ ${ }^{1}$ Department of Biology, Faculty of Mathematics and Natural Sciences, Univetsitas Padjadjaran. Jl. Raya Bandung Sumedang Km. 21, Jatinangor, \\ Sumedang 45363, West Java, Indonesia. Tel./fax.: +62-22-84288898, `email: dkdwiki4@ gmail.com. \\ ${ }^{2}$ Indonesia Power. Jl. Komplek Perumahan PLTP Kamojang, Kotak Pos 125, Garut 44101, West Java, Indonesia. \\ Tel.: +62-22-7805475, Fax.; +62-22-7801013, "email: femi.afriyanti@indonesiapower.co.id
}

Manuscript received: 7 November 2019. Revision accepted: 31 March 2020.

\begin{abstract}
Kuncoro DD, Husodo T, Kusmoro J, Hendrawan R, Suroso, Afriyanti F, Megantara EN. 2020. Above-ground carbon stock at Kamojang Regions, West Java, Indonesia. Biodiversitas 21: 1749-1754. Kamojang is one of the regions that have the potential for carbon dioxide $\left(\mathrm{CO}_{2}\right)$ sequestration and carbon storage for the southern side of West Java Province, Indonesia. The existence of vegetation as a provider of ecological services in the form of carbon dioxide $\left(\mathrm{CO}_{2}\right)$ absorption and carbon storage certainly has a very important role, either in living conditions (biomass) or dead conditions (necromass). The aims of this study are to determine the total amount of above-ground carbon stock and determine the type of land-use that has the greatest carbon storage potential in the Kamojang region. Data collection in this research combines destructive and non-destructive methods. The measurement of biomass was carried out by the non-destructive sampling method for the category of sapling, poles, trees and necromass and the destructive sampling method for the category of undergrowth and litter. The results showed total above-ground carbon stored in Kamojang area is 4,995.75 t $\mathrm{C}$ with the largest potential value of carbon stock in the pine production forest of $163.79 \mathrm{t} \mathrm{C} / \mathrm{ha}$.
\end{abstract}

Keywords: Carbon, carbon stock, greenhouse effect, vegetation

\section{INTRODUCTION}

Global warming is a condition where the earth's surface temperature increases and can threaten the lives of all organisms on the earth's surface. Global warming is an impact of an imbalance of carbonic acid gas concentration in the atmosphere, resulting in the greenhouse effect. Charcoal gas absorbs and traps solar radiation in the atmosphere in the form of heat energy, the accumulation of heat energy in the atmosphere causes an increase in the earth's surface temperature which then known as global warming.

One of the charcoal gases playing a big role in global warming is carbon dioxide $\left(\mathrm{CO}_{2}\right) \cdot \mathrm{CO}_{2}$ is a gas that is produced from various activities such as industrial activities, the use of motorized vehicles, combustion from power plants (with the use of coal, gas or oil), forest fires, and others. Liu et al. (2017) stated that the level of $\mathrm{CO}_{2}$ in the atmosphere will continue to increase so that climate warming will become the main feature of future climate change. The interaction between $\mathrm{CO}_{2}$ and temperature will certainly exert a profound influence on the earth's environment.

Increasing $\mathrm{CO}_{2}$ concentration in the atmosphere can be minimized by plants' ecological functions, such as absorbing and reducing carbon dioxide $\left(\mathrm{CO}_{2}\right)$. Brown (1997) states that plants absorb $\mathrm{CO}_{2}$ from the air and then convert it into organic matter through the photosynthesis process used for growth. Maiti et al. (2015) also state that plants contribute to the capture of carbon dioxide in the process of photosynthesis, and store carbon in its biomass. According to the IPCC (2007), there are 5 carbon sources, namely: above-ground biomass, below-ground biomass, dead trees, litter, and soil. There are differences between the amounts of carbon stored in each carbon source due to differences in plant species. These different types of plants have an impact on the differences in density and carbon storage capacity of these plants.

Vegetation is an important asset in the absorption of carbon dioxide $\left(\mathrm{CO}_{2}\right)$ in the atmosphere. In this case, the management of an area with good vegetation can be a solution to the problems arising from global warming because this area has a potential for carbon sequestration and storage from five sources that have been defined by IPCC. One of the vegetation assets owned by West Java province in the southern region is Kamojang area that managed by PT Indonesia Power Kamojang and Perhutani. Kamojang area itself does not yet have information on the potential for carbon sequestration and storage, so a study is needed to know the potential for carbon sequestration and storage contained in this area so it can become a reference for future management of this area.

\section{MATERIALS AND METHODS}

Research on carbon storage is done on July $30^{\text {th }}$-August $3^{\text {rd }} 2019$ and located in Kamojang Region, Samarang Sub- 
district, Bandung District, West Java, Indonesia. Carbon data collection in this area includes 4 objects, consisting of tree biomass within three phases (sapling, pole, and tree), undergrowth biomass, tree necromass, and litter necromass. Both carbon and Importance value index (IVI) sampling was determined by means of random with an intensity of $5 \%$ and distributed into 58 plots of $20 \mathrm{~m} \times 20 \mathrm{~m}$.

The collection of tree and necromass data is carried out by a non-destructive method with the parameters of species, diameters at breast height and height/length, while the collection of undergrowth and litter data is carried out by destructive method with the parameters of type, total wet weight, sample of wet weight, and sample of dry weight. The data that has been taken then is analyzed using the allometric formula so that carbon storage data is obtained from each object in each sampling area.

Importance value index (IVI) data collection is used to determine the dominant type of plant in the study area. Wiryani et al. (2018) state that IVI indices of vegetation are indicators for ecological role of vegetation structure in respective ecosystem.

The sampling of carbon data is done by random sampling in each area so it can obtain representative data on the total condition of carbon storage in the study area. The size of the IVI and carbon data collection plot can be seen in Table 1.

Measurement of tree biomass in the study area is grouped based on three phases of vegetation (seedling, pole, and tree). Vegetation biomass calculations are done by using the allometric equation used by Chave et al. (2005).

\section{Dry weight-Biomass $=0.0509 \times \pi \mathrm{D}^{2} \mathrm{H}$}

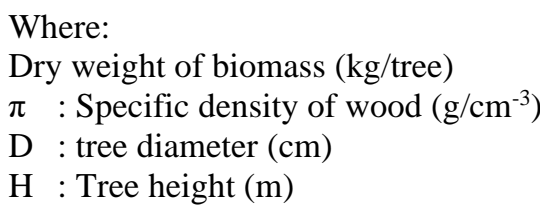

Necromass carbon is measured on dead trees that either still stood upright or collapsed. Necromass calculations are done by the SNI method (BSN 2011), based on the data of tree species, diameter, height/length, and the level of tree integrity. The necromass data was calculated using the allometric equations according to the tree species. Dead tree necromass is obtained by multiplying the tree necromass and the correction factor. The correction factor is determined based on the level of integrity of the dead tree with the following classification: (i) Dead trees without leaves with a correction factor of 0.9. (ii) Dead trees without leaves and twigs with a correction factor of 0.8 . (iii) Dead trees without leaves, twigs, and branches with a correction factor of 0.7 .

In addition to dead trees, necromass carbon measurements are also carried out by dead trees diameter (base and tip diameter), dead trees length, and its specific density. Based on these data, the biomass of deadwood is calculated by the SNI formula from BSN (2011).

$$
\mathrm{B}=\mathrm{v} \times \mathrm{WD}
$$

Where:

B : Deadwood necromass

$\mathrm{V}$ : Volume of deadwood

WD : Specific density of deadwood

Undergrowth biomass and litter were measured by destructive methods on a $2 \mathrm{~m} \times 2 \mathrm{~m}$ plot. All undergrowth and litter in the plot are taken then weighed to know the wet weight. If the total wet weight of litter is more than 300 $\mathrm{g}$, only $300 \mathrm{~g}$ of wet weight sample is taken. The litter sample is then heated in an oven at $80^{\circ} \mathrm{C}$ for 48 hours to measure its dry weight. Litter biomass can be calculated using the following Biomass Expansion Factor formula (Brown 1997):

$$
\text { Biomass }=\frac{\text { Sample dry weight }}{\text { Sample wet weight }} \times \text { wet weight total }
$$

Carbon storage is calculated based on biomass and necromass data that have been obtained in trees, necromass, litter, and undergrowth. Carbon estimation is calculated based on the carbon calculation formula according to SNI from BSN (2011).

\begin{tabular}{|c|c|c|c|c|}
\hline Component & Definition & Method & Plot size & The data that collected \\
\hline \multicolumn{5}{|l|}{ IVI data } \\
\hline Tree & Tree data with $\mathrm{dbh}>20 \mathrm{~cm}$ & Non-destructive & $10 \times 10 \mathrm{~m}^{2}$ & Species name, and diameter (dbh) \\
\hline Pole & Pole data with dbh $10>d b h>20 \mathrm{~cm}$ & Non-destructive & $8 \times 8 \mathrm{~m}^{2}$ & Species name, and diameter (dbh) \\
\hline Seedling & Seedling data with $\mathrm{dbh}<10 \mathrm{~cm}$ & Non-destructive & $4 \times 4 m^{2}$ & Species name, and diameter (dbh) \\
\hline \multicolumn{5}{|l|}{ Carbon data } \\
\hline Tree & Tree data with $\mathrm{dbh}>20 \mathrm{~cm}$ and necromass & Non-destructive & $20 \times 20 \mathrm{~m}^{2}$ & Species name, diameter (dbh), height \\
\hline Necromass & $\begin{array}{l}\text { All dead trees that either still stood upright } \\
\text { or collapsed }\end{array}$ & Non-destructive & $20 \times 20 \mathrm{~m}^{2}$ & $\begin{array}{l}\text { Species name, diameter (dbh), height/ } \\
\text { length, and the level of tree integrity }\end{array}$ \\
\hline Pole & Pole data with dbh $10>d b h>20 \mathrm{~cm}$ & Non-destructive & $10 \times 10 \mathrm{~m}^{2}$ & Species name, diameter (dbh), height \\
\hline Seedling & Seedling data with $\mathrm{dbh}<10 \mathrm{~cm}$ & Non-destructive & $5 \times 5 \mathrm{~m}^{2}$ & Species name, diameter (dbh), height \\
\hline $\begin{array}{l}\text { Undergrowth and } \\
\text { necromass }\end{array}$ & $\begin{array}{l}\text { All the undergrowth and litter that was } \\
\text { found in the plot area }\end{array}$ & Destructive & $2 \times 2 m^{2}$ & $\begin{array}{l}\text { Species name, total wet weight } \\
\text { biomass, dry weight sample, and wet } \\
\text { weight sample }\end{array}$ \\
\hline
\end{tabular}

Table 1. The data that were collected on Kamojang Carbon Research 2019, West Java, Indonesia 
$\mathrm{C}=$ Biomass (or Necromass) $\mathrm{x} 47 \%$

Where:

C: Carbon

The total carbon stock in the area is calculated using the following equation (BSN 2011).

Total C $=\frac{\sum \mathrm{C} \text { plot }}{\mathrm{n} \text { plot }} \times$ Area

Where:

Total C : total carbon stock ( $\mathrm{t}$ C)

n plot : Number of plots

C plot : total carbon content per hectare (t C/ha)

Area : total area of land (ha)

\section{RESULTS AND DISCUSSION}

\section{Results}

In general, carbon stock research areas cover the Kamojang area. Administratively, this area is located in the Samarang Sub-district, Bandung District, West Java,
Indonesia. The carbon storage research area has 5 types of land-use including; pine production forest, rasamala (Altingia excelsa) production forest, riparian, arboretum, and mixed land (agriculture and tree stand). The map of the Kamojang carbon stock study can be seen in Figure 3.

The black dots in Figure 1 show the carbon sampling plot of the 2019 carbon storage data collection that consists of 5 types of land-use. Total carbon stock research area in the Kamojang is 42.6 ha. Carbon stock study is a method used to obtain information about the potential storage of carbon stock in a particular area for a particular purpose. In this study, a carbon storage study was carried out on vegetation in the Kamojang area where the carbon source objects studied including trees (sapling, poles, and trees), undergrowth, necromass, and litter.

Data collection in the research area is based on sampling with an intensity of $5 \%$ of total research area. The calculation of carbon stock estimation is based on the specific density of each carbon source object which is then converted to biomass or necromass. Biomass or necromass data is then analyzed using allometric formula (Chave et al. 2005) to obtain data for estimating carbon storage. The results of carbon storage calculations in this study are presented in Table 1.
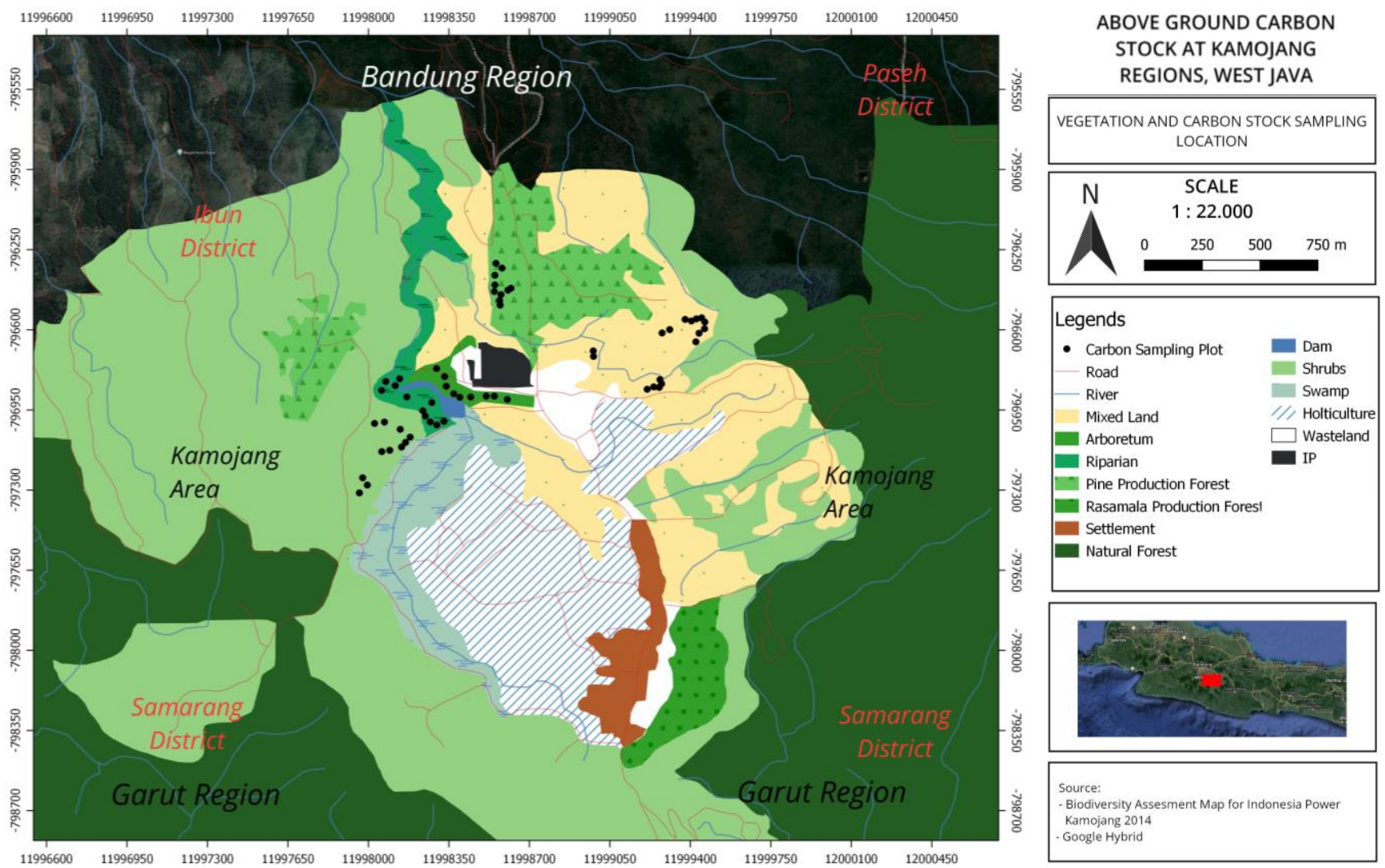

Figure 1. Map of Kamojang carbon storage data 2019, West Java, Indonesia 
Table 2. Carbon stock calculation results in the Kamojang area, West Java, Indonesia

\begin{tabular}{|c|c|c|c|c|c|c|c|}
\hline land-use & $\begin{array}{l}\text { Carbon from } \\
\text { tree biomass } \\
\text { (t C/ha) }\end{array}$ & $\begin{array}{c}\text { Carbon from } \\
\text { undergrowth biomass } \\
\text { (t C/ha) }\end{array}$ & $\begin{array}{c}\text { Carbon } \\
\text { from litter } \\
\text { (t C/ha) }\end{array}$ & $\begin{array}{c}\text { Carbon from } \\
\text { necromass } \\
\text { (t C/ha) }\end{array}$ & $\begin{array}{c}\text { Area } \\
\text { (ha) }\end{array}$ & $\begin{array}{c}\text { Carbon } \\
\text { stock } \\
\text { (t C/ha) }\end{array}$ & $\begin{array}{c}\text { Total carbon } \\
\text { stock } \\
(t \text { C) } \\
\end{array}$ \\
\hline Rasamala production forest & 79.77 & 0.3 & 2.33 & 1.19 & 8.8 & 83.60 & 735.71 \\
\hline Arboretum & 94.61 & 0.34 & 1.35 & 0 & 6 & 96.30 & 577.83 \\
\hline Riparian & 141.33 & 0.35 & 2.14 & 0 & 8.8 & 143.82 & $1,265.69$ \\
\hline Pine production forest & 162.25 & 0.27 & 1.26 & 0 & 6 & 163.79 & 982,77 \\
\hline Mixed land & 96.33 & 0.13 & 0.75 & 13.0 & 13 & 110.28 & $1,433.73$ \\
\hline \multicolumn{5}{|c|}{ Total } & 42.6 & & $4,995.73$ \\
\hline
\end{tabular}

\section{Discussion}

Based on the 2019 Kamojang carbon stock studies, there are 5 types of land-use, namely rasamala production forest, pine production forest, arboretum, riparian, and mixed land. Each type of land-use has the ability to absorb and store carbon but with different abilities based on the condition of carbon source in each type of land-use. The result shows that the pine production forest has the highest carbon storage value per hectare i.e. $163.79 \mathrm{t} \mathrm{C/ha}$ and the rasamala production forest has the lowest carbon storage value per hectare i.e. $83.60 \mathrm{t} \mathrm{C/ha.} \mathrm{However,} \mathrm{there} \mathrm{are} \mathrm{other}$ factors than the type of land-use that can affect total carbon storage value in this area, such as vegetation structure and composition, an anthropogenic activity that happens in this area and total area coverage.

Vegetation structure and composition affect the ability of a specific land-use to absorb and store carbon because every specific land-use consists of vegetation that has a different ability to absorb and store carbon. An anthropogenic activity also affects the ability of a specific land-use to absorb and store carbon because if an area were well-managed then it'll give a good impact on carbon sequestration and stock ability. A good management intervention can give a good impact on carbon storage in an area, on the other hand, a bad management intervention such as illegal logging or exploitation can give a bad impact on carbon storage in an area. The total coverage of an area can affect the total carbon storage value because even if an area has a small carbon stock potential per hectare it will have a huge total carbon stock value if the vegetation covers a huge area. The bigger coverage of an area, the bigger ability of this area to stock carbon. This is proven by the type of mixed land that has the largest total carbon storage value namely $1,433.73$ tons with a total area coverage of 13 hectares and the arboretum having the lowest total carbon storage value of 577.83 tons with a total area coverage of 6 hectares.

Based on Table 2, it is shown that the pine production forest has the largest carbon stock value per hectare but it didn't have the largest total carbon stock value. This could happen because the pine production forest area only covers 6 hectares. The pine production forest is also a monoculture type of vegetation so there is no vegetation composition variety and almost no vegetation structure variety in this type of land-use because it is planted in relatively same time with the same kind of plants. On the other hand, the mixed land has the largest total carbon stock value but it didn't have the largest carbon stock value per hectare. This could happen because the mixed land area covers 13 hectares. The mixed land consists of a different kind of vegetation structure and composition so this area also consists of different kinds of carbon sequestration and stock ability, so that the mixed land didn't have the largest carbon value per hectare.

Based on Table 2, the type of land-use that has the largest carbon storage value per hectares is the pine production forest. Based on calculations, the pine production forest area has a carbon storage potential of 982.77 t $\mathrm{C}$ with an average carbon storage potential per hectare of $163.79 \mathrm{t} \mathrm{C/ha}$. Pine production forests have very high carbon storage values per hectare. This happens because the stands owned by this type of land-use have a high density and old age. However, this area is smaller when compared to mixed land so that the total carbon stock area in this region is smaller.

Based on the literature study, carbon stock in pine production forests area in the Kamojang shows a pretty good number when compared with previous research conducted by Cheng et al. (2014), namely variation in biomass and carbon storage by stand age in pine planted ecosystem in Mt. Taiyue, Shanxi, China is $137.71 \mathrm{t} \mathrm{C} / \mathrm{ha}$. This high carbon stock condition can occur due to the age of vegetation stand, and density at the time of planting. In addition, management in the form of intercropping of coffee can also influence the potential conditions for carbon storage in Kamojang.

Another factor that influences the condition of carbon storages in pine production forest is the presence of tree vegetation which has a total canopy cover of $85-90 \%$. Canopy cover in the area of pine production forest will affect the ecological condition of the undergrowth because the high cover canopy will have an impact on the light intensity that can touch the ground floor. If the light intensity on the ground floor has a low value then the undergrowth will have a low survival rate so that its presence will be difficult to find, and the undergrowth area will have low carbon storage. The pine production forest has a very high canopy cover value so that the sunlight will hardly touch the ground floor and the presence of undergrowth as carbon sequestrate and storage is in a bad condition, this is evidenced by the cover of undergrowth which only reaches a number of $10-15 \%$.

Based on the vegetation analysis, it is found that in the pine production forest, pine (Pinus merkusii) occupies the 
highest relative dominance value for tree and pole phase with relative dominance values of $93.73 \%$ and $97.8 \%$ respectively, and coffee (Coffea arabica) occupies the highest relative dominance value for the seedling phase with a relative dominance value of $100 \%$. The relative dominance value can also show a condition of the potential contribution of carbon storage of a species in the study area. The higher the relative dominance value of a species, the higher the carbon storage contribution potential of that species in the study area. In pine production forests, pine (P. merkusii) are the most dominant species because this forest is monocultures with only pine planted in this area and also managed intensively. In addition to relative dominance, wood density values can also have an impact on carbon storage contributions. The higher the density of wood, the higher the carbon storage potential of a species. In the pine production forest, species that have the highest density are Peutag (Syzygium densiflorum) with a wood density of 0.660 , coffee (C. arabica) with a wood density of 0.620 , and pine (P. merkusii) with a wood density of 0.530 .

Figure 2 is a comparison between conditions of carbon stocks in each land-use in the Kamojang based on 2019 carbon study and a literature study on these researches, namely Ostadhashemi et al. (2014) for Rasamala Production Forest, Chazdon et al. (2016) for Arboretum, Nunes (2018) for Riparian, Gong et al. (2019) for Mixed Land, and Cheng et al. (2014) for Pine Production Forest.

Based on Figure 2 it can be seen that in general, the Kamojang area has a very good carbon storage value when compared to carbon storage studies on each type of landuse that has been carried out before. This shows the positive results of environmental management that have been carried out in the Kamojang area. But we can also see that the mixed land in the Kamojang area has a lower carbon stock value per hectare compared to a carbon stock study in mixed land that has been carried out by Gong et al. (2019). This is caused by a different kind of vegetation structure and composition that constructs mixed land in the Kamojang area and in the area in the previous study by Gong et al. (2019). The Mixed land in the Kamojang area is consistently managed by local resident by intercropping several plants such as Coffee (C. arabica), East African mahogany (Khaya anthoteca), Banana (Musa $x$ paradisiaca), white gum (Eucalyptus alba), and Pine ( $P$. merkusii).

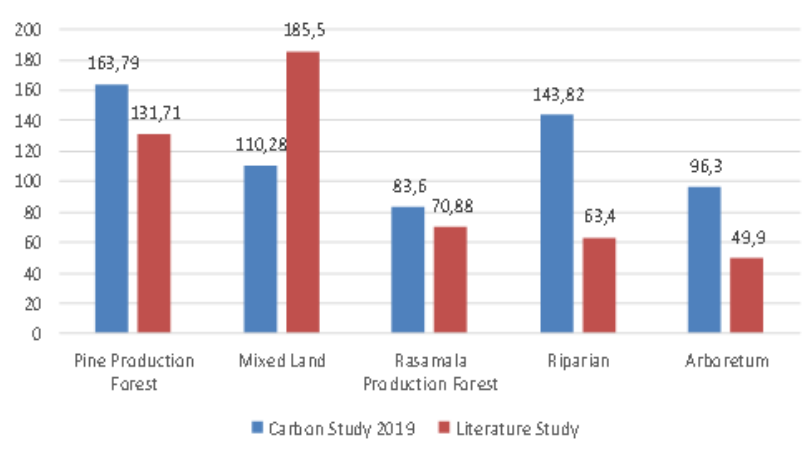

Figure 2. Comparison of carbon values (t C/ha) of Kamojang, West Java, Indonesia with literature
The difference in carbon stock condition in the Kamojang area and the literature study can occur due to the difference of age and vegetation composition. Another factor that influences the condition of carbon storages in mixed land is the presence of tree vegetation which has a total canopy cover of $10-50 \%$. Canopy cover in the area of the mixed land will affect the ecological condition of the undergrowth because the high cover canopy will have an impact on the light intensity that can touch the ground floor. If the light intensity on the ground floor has a low value then the undergrowth will have a low survival rate so that its presence will be difficult to find, and the area will have low carbon storage in the undergrowth. The mixed land has a low canopy cover value so that the sunlight will easily touch the ground floor and the presence of undergrowth as carbon sequestrate and storage is in a good condition, this is evidenced by the cover of undergrowth which only reaches a number of $70-80 \%$.

Based on the vegetation analysis, it is found that in the mixed land, white gum (E. alba) occupies the highest relative dominance value for tree and pole phase with relative dominance values of $58.06 \%$ and $53.82 \%$ respectively, and coffee ( $C$. arabica) occupies the highest relative dominance value for the seedling phase with a relative dominance value of $100 \%$. The relative dominance value can also show a condition of the potential contribution of carbon storage of a species in the study area. The higher the relative dominance value of a species, the higher the carbon storage contribution potential of that species in the study area. The higher the density of wood, the higher the carbon storage potential of a species. In the mixed land, species that have the highest density are white gum (E. alba) with a wood density of 0.916 , Lithocarpus elegans with wood density of 0.799 , and white lead tree (Leucaena leucocephala) with wood density of 0.760 .

The total carbon stock that stored in the Kamojang area is $4,995.75 \mathrm{t} \mathrm{C}$. This value shows a pretty good number when compared to carbon studies that have been done previously where there is a higher carbon stock value per hectare in each type of land-use in the Kamojang area.

A good forest or vegetation area has a lot of benefits, in relation to global warming and climate change issues, namely forests area have the function to reduce $\mathrm{CO}_{2}$ emissions that were released into the atmosphere and then stored in the form of carbon stocks. Ontl et al. (2020) stated that managing for forest carbon under changing climatic conditions underscores a need for resources that help identify adaptation actions that align with carbon management. With the management carried out by PT Indonesia Power Kamojang and Perhutani, the Kamojang area can become one of the alternative solutions to environmental problems, such as global warming or climate change in West Java specifically in the southern region that can arise due to increased atmospheric $\mathrm{CO}_{2}$ concentrations through $\mathrm{CO}_{2}$ absorption.

In conclusion, the total aboveground carbon stock of the Kamojang area which includes pine production forest, rasamala production forest, riparian, arboretum, and mixed land is 4,995,755 t C. Compared to other types of land-use, Pine production forest has the largest potential carbon stock 
per hectare value namely $163.79 \mathrm{t} \mathrm{C} / \mathrm{ha}$. However, the largest area of carbon stock appears in mixed land, i.e. $1,433.73 \mathrm{t} \mathrm{C}$, because mixed land has the largest area even though the carbon storage value per hectare is lower than pine production forests.

\section{ACKNOWLEDGEMENTS}

Sincere gratitude to those who contributed and supported this research, Departement of Biology and Center of Ecological and Sustainability Science, Universitas Padjadjaran, Sumedang, Indonesia, which has provided administrative support in this research, Biology Preparation Laboratory, Universitas Padjadjaran, Sumedang, Indonesia which has provided an infrastructure for data analysis, Indonesia Power Kamojang, which has provided administrative support and funded this research.

\section{REFERENCES}

Brown S. 1997. Estimating Biomass and Biomass Change of Tropica Forests: a Primer. (FAO Forestry Paper-134). Food and Agriculture Organization of the United Nations, Rome.

BSN [Badan Standardisasi Nasional]. 2011. Measurement and Calculation of Carbon Reserves. Field Measurement for Ground-Based Forest Carbon Accounting. National Standardization Agency. Jakarta. [Indonesian]

Chave J, Andalo C, Brown S, Cairns M A, Chambers J Q, Eamus D, Folster H, Fromard F, Higuchi N, Kira T, Lescure JP, Nelson B W, Ogawa H, Puig H, Riera B, Yamakura T. 2005. Tree allometry and improved estimation of carbon stocks and balance in tropical forests. Oecologia. 145:87-99. DOI: 10.1007/s00442-005-0100-x.

Chazdon RL, Broadbent EN, Rozendaal DMA, et al. 2016. Carbon sequestration potential of second-growth forest regeneration in the Latin American tropics. Sci Adv 2 (5): e1501639. DOI: 10.1126/sciadv. 1501639 .

Cheng XQ, Han HR, Kang FF, Song Y, Liu K. 2014. Variation in biomass and carbon storage by stand age in pine planted ecosystem in Mt. Taiyue, Shanxi, China, J Plant Interact 9 (1): 521-528. DOI: 10.1080/17429145.2013.862360.

Gong Z, Tang Y, Xu W, Mou Z. 2019. Rapid Sequestration of Ecosystem Carbon in 30-year Reforestation with Mixed Species in Dry Hot Valley of the Jinsha River. Intl J Environ Res Publ Health 16 (11) 1937. DOI: $10.3390 /$ ijerph16111937.

Intergovernmental Panel on Climate Change (IPCC). 2007. Intergovernmental Panel on Climate Change Guidelines for National Greenhouse Gas Inventories: Chapter 5. IGES. Japan.

Liu S, Waqas MA, Wang Sh, Xiong Xy, Wan Yf. 2017. Effects of increased levels of atmospheric $\mathrm{CO} 2$ and high temperatures on rice growth and quality. PLoS ONE 12 (11): e0187724. DOI: 10.1371/journal.pone.0187724.

Maiti R, Rodriguez HG, Kumari Ch A. 2015. Trees and Shrubs with High Carbon Fixation/Concentration. Forest Res S1: 003. DOI: 10.4172/2168-9776.S1-003.

Nunes MH, Terra Marcella de Castro NS, de Oliveira IRC, van den Berg E. 2018. The influence of disturbance on driving carbon stocks and tree dynamics of riparian forests in Cerrado. J Plant Ecol 11 (3): 401 410.

Ontl TA, Janowiak MK, Swanston CW, Daley J, Handler S, Cornett M, Hagenbuch S, Handrick C, Mccarthy L, Patch N, 2020. Forest management for carbon sequestration and climate adaptation. J For 118 (1): 86-101.

Ostadhashemi R, Shahraji TR, Roehle H, Limaei SM. 2014. Estimation of biomass and carbon storage of tree plantations in northern Iran. J For Sci 60 (9):363-371

Wiryani E, Murningsih, Jumari. 2018. The abundance and importance value of tree in "Sendang Kalimah Toyyibah" surrounding and its implication to the spring. IOP Conf. Ser J Physics Conf. Ser 1025: 012032. DOI: 10.1088/1742-6596/1025/1/012032. 